\title{
Inexplicable infantile cataracts and partial maternal galactose disorder
}

\author{
M BRIVET, V ABADIE, T SONI, G CHERON, AND J L DUFIER
}

Department of Biochemistry, Bicêtre Hospital, and Department of Pediatrics, Necker - Enfants Malades Hospital, Paris, France

SUMmaRY Previous reports have suggested that partial maternal deficiency of galactose metabolising enzymes, particularly of galactokinase activity, could contribute to the formation of cataracts during developmental life, even in a fetus that is enzymatically normal. We have assayed erythrocyte galactokinase and uridyltransferase activities in 12 families with children suffering early onset cataracts. We did not observe any abnormality of galactose metabolising enzymes in either the mothers or the infants. Furthermore, we have looked for the occurrence of cataracts among children of seven mothers heterozygous for one of these two deficiencies. No children with enzyme activity in the normal or heterozygous range had cataracts.

Two genetically determined disorders involving an enzymatic defect in the main galactose metabolic pathway (Figure) are associated with cataracts. The

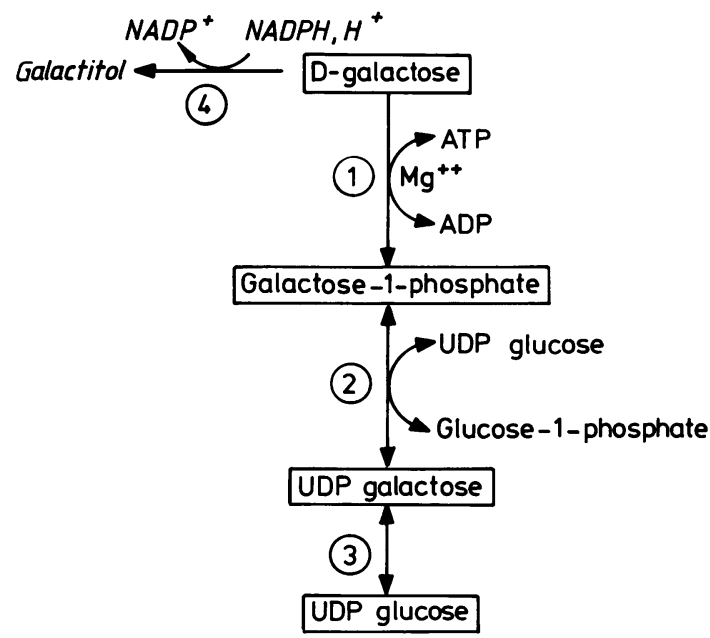

$\left\{\begin{array}{l}\text { (1) } \\ \text { (2) }\end{array}\right.$ Galactokinase

(4) Aldose reductase

(2) Uridyltransferase

Figure Main galactose pathway (1, 2, and 3) and alternative route responsible for the formation of galactitol (4).

$\mathrm{NADP}=$ nicotinamide-adenine-dinucleotide phosphate: $\quad$ NADPH $=$ NADP (reduced form): T TP= adenosine triphosphate: $A D P=$ adenosine diphosphate: UDP $=$ uridine diphosphate first is uridyltransferase (EC 2.7.7.12.) deficiency, which has long been known as galactosaemia, the other is galactokinase (EC 2.7.1.6) deficiency. Both are autosomal recessive traits. In contrast to the multiple systems affected in galactosaemia, cataract formation is usually the sole stigma in galactokinase deficiency. Early diagnosis and dietary control of these disorders can prevent cataracts and even achieve regression in some cases. The mechanism of cataract formation involves the reduction of galactose to galactitol within the lens. This polyol cannot diffuse out of the lens: it exerts an osmotic effect leading to disruption of the lens fibres. The prevalence of galactokinase deficiency is not well defined $\left(1 / 40000\right.$ to $\left.1 / 10^{6}\right)$, but it is certainly less than for galactosaemia (1/62 000). ${ }^{\text {' }}$

Presenile cataracts have been described in heterozygous patients with galactokinase deficiency, ${ }^{2.3}$ but other authors, in a larger number of subjects, found no relation between cataracts and partial deficiency. ${ }^{45}$ Heterozygous subjects with uridyltransferase deficiency seem not to have any risk of cataract, although two of 22 patients with presenile cataracts were reported to have a partial deficiency. ${ }^{2}$

Previous reports have also suggested that partial maternal deficiency, particularly of galactokinase activity, can contribute to the formation of cataracts in utero, even in a fetus that is enzymatically normal. ${ }^{5}{ }^{6}$ In view of this hypothesis we have assayed erythrocyte activities of galactokinase and uridyltransferase in families with children suffering from early onset cataracts and have looked for the 
incidence of cataracts among children of mothers heterozygous for these enzyme deficiencies.

\section{Material and methods}

Patients. Two groups of patients were investigated.

Group 1 comprised 24 children with early onset bilateral cataracts and their 12 mothers. The cataracts were observed at birth or in the first few months of life and could not be explained by any specific aetiological factor.
Group 2 comprised seven mothers and their 16 children. Two of these seven mothers had a partial galactokinase deficiency (case 13 was the aunt of a child with homozygous galactokinase deficiency, case 14 happened to be identified in a control group). Four had a partial transferase deficiency, being mothers of children with galactosaemia. One mother (case 19) was explored because she developed cataract during her pregnancy, and she was found to be heterozygous for the transferase deficiency.

Table 1 Erythrocyte activities of galactokinase and uridyltransferase in children with cataracts and their mothers

\begin{tabular}{|c|c|c|c|c|c|c|c|c|c|}
\hline \multicolumn{4}{|c|}{ Mothers } & \multicolumn{6}{|c|}{ Children } \\
\hline $\begin{array}{l}\text { Case } \\
\text { No }\end{array}$ & Cataract & $\begin{array}{l}\text { Galactokinase } \\
(\mu \mathrm{mol} / \mathrm{min} / \mathrm{kg} \mathrm{Hb})\end{array}$ & $\begin{array}{l}\text { Uridyltransferase } \\
\text { (umol/min/kg } \mathrm{Hb})\end{array}$ & Sex & $\begin{array}{l}\text { Age at } \\
\text { testing }\end{array}$ & & $\begin{array}{l}\text { Age at which } \\
\text { cataract noted }\end{array}$ & $\begin{array}{l}\text { Galactokinase } \\
(\mu \mathrm{mol} / \mathrm{min} / \mathrm{kg} \mathrm{Hb})\end{array}$ & $\begin{array}{l}\text { Uridyltransferase } \\
(\mu \mathrm{mol} / \mathrm{min} / \mathrm{kg} \mathrm{Hb})\end{array}$ \\
\hline 1 & & 29 & 418 & $M$ & 2.5 months & + & 2.5 months & $58 \cdot 1$ & 473 \\
\hline 2 & & 21 & 417 & $\mathrm{~F}$ & 3 months & + & 3 months & 38 & 427 \\
\hline \multirow[t]{3}{*}{3} & & $21 \cdot 5$ & 373 & $\mathrm{~F}$ & 9 years & + & Neonatal & 28.9 & 512 \\
\hline & & & & $\mathrm{M}$ & 19 years & + & 15 years & $24 \cdot 3$ & 698 \\
\hline & & & & $\mathbf{F}$ & 21 years & + & 4 years & $22 \cdot 6$ & 737 \\
\hline 4 & + & 21.9 & 332 & $\mathrm{~F}$ & 1 year & + & Neonatal & $27 \cdot 1$ & 473 \\
\hline 5 & + & 42 & Normal* & $\mathrm{F}$ & 8 days & + & Neonatal & $82 \cdot 6$ & Normal* \\
\hline 6 & & $24 \cdot 2$ & 415 & $\mathrm{~F}$ & 4 months & + & Neonatal & 44 & 613 \\
\hline \multirow[t]{2}{*}{7} & & 26 & 518 & $\mathbf{M}$ & 5 months & + & 4 months & 54.9 & 579 \\
\hline & & & & \multicolumn{6}{|c|}{ Two asymptomatic siblings } \\
\hline 8 & & $28 \cdot 1$ & 450 & M & 4 months & + & 4.5 months & $41 \cdot 6$ & $5(1) 5$ \\
\hline \multirow[t]{3}{*}{9} & + & $21 \cdot 7$ & 445 & $\mathrm{~F}$ & 1 year & + & Neonatal & 49 & 436 \\
\hline & & & & $\mathrm{F}$ & 6 years & + & Neonatal & $26 \cdot 9$ & 495 \\
\hline & & & & $\mathrm{F}$ & 5 years & + & Neonatal & $27 \cdot 7$ & 500 \\
\hline 10 & & $31 \cdot 4$ & 44.5 & $\mathrm{~F}$ & 5 months & + & 2 months & $46 \cdot 8$ & 504 \\
\hline 11 & & $26 \cdot 3$ & 419 & $\mathrm{~F}$ & 2 years & + & Neonatal & $31 \cdot 1$ & 447 \\
\hline \multirow[t]{2}{*}{12} & + & $19 \cdot 2$ & 417 & $\mathrm{M}$ & 4 years & + & 10 months & $25 \cdot 8$ & 477 \\
\hline & & & & \multicolumn{6}{|c|}{ Six asymptomatic siblings } \\
\hline Mean & & $26 \cdot 0$ & $422 \cdot 6$ & & & & & & \\
\hline SD & & $6 \cdot 2$ & $46 \cdot 6$ & & & & & & \\
\hline
\end{tabular}

Reference values for adults: mean (2 SD) galactokinase $(\mathrm{n}=87)=28 \cdot 5(11 \cdot 2) \mu \mathrm{mol} / \mathrm{min} / \mathrm{kg} \mathrm{Hb}$ : mean $(2 \mathrm{SD})$ uridyltransferase $(\mathrm{n}=128)=421(132) \mu \mathrm{mol} / \mathrm{min} / \mathrm{kg} \mathrm{Hb}$ *Screening method of Beutler and Baluda to test uridyltransferase activity. ${ }^{11}$

Table 2 Prevalence of cataracts in children of mothers with a partial galactokinase or uridyltransferase deficiency

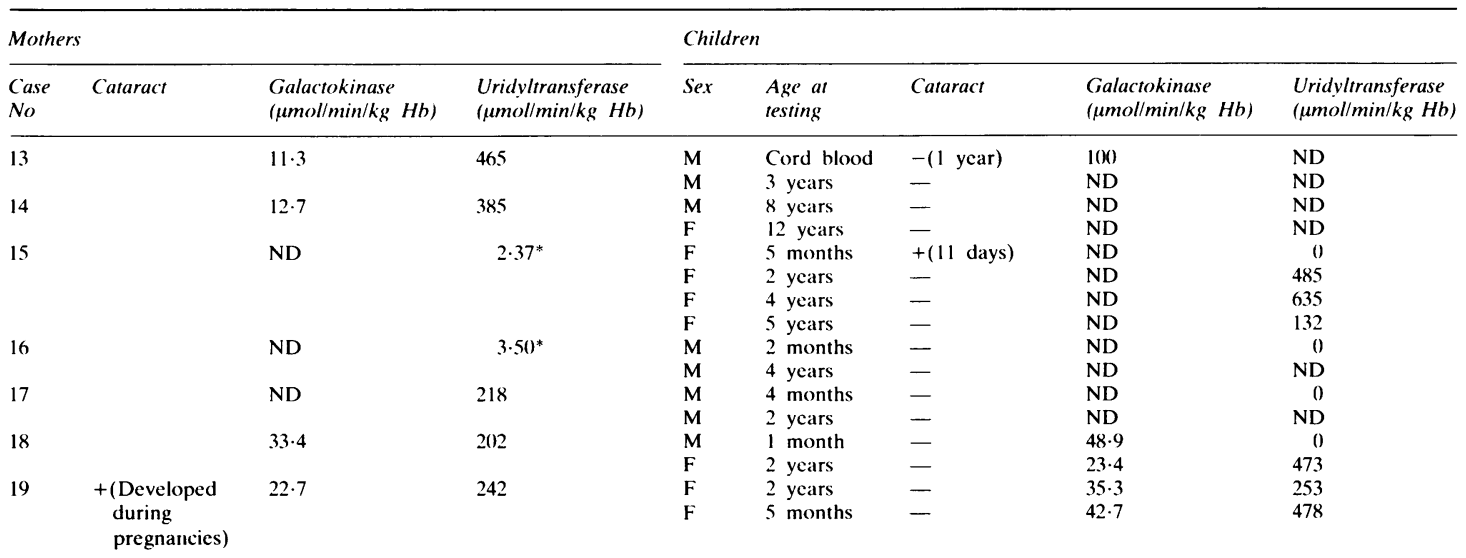

Reference values for adults: mean (2SD) galactokinase $(\mathrm{n}=87)=28 \cdot 5(11 \cdot 2) \mu \mathrm{mol} / \mathrm{min} / \mathrm{kg} \mathrm{Hb} ; \mathrm{mean}(2 \mathrm{SD})$ uridyltransferase $(\mathrm{n}=128)=421(132) \mu \mathrm{mol} / \mathrm{min} / \mathrm{kg} \mathrm{Hb}$, $7 \cdot(0)(2 \cdot 26) \mu \mathrm{mol} / \mathrm{h} / \mathrm{ml}$ erythrocytes.

*Values expressed by $\mathrm{ml}$ of packed erythrocytes (hypochromic anaemia). 
Methods. Erythrocyte galactokinase and uridyltransferase activities were assayed by isotopic methods using $\left(1-{ }^{14} \mathrm{C}\right)$ galactose and $\left(\mathrm{u}-{ }^{14} \mathrm{C}\right)$ galactose1-phosphate, respectively, as substrates. ${ }^{7}{ }^{8}$

Control values (mean (2 SD)) for galactokinase activity in adults and children above 2 years of age were $28.5(11.2) \mu \mathrm{mol} / \mathrm{min} / \mathrm{kg}$ haemoglobin $(\mathrm{n}=87)$. Galactokinase activity of the infant is three times higher: it decreased during the first year of life; at one year its level is about 1.5 times the adult value."

Control values (mean (2 SD)) for uridyltransferase activity were 421 (132) $\mu \mathrm{mol} / \mathrm{min} / \mathrm{kg}$ haemoglobin $(\mathrm{n}=128)$ for infants, children, and adults.

Haematological counts were performed to detect patients with microcytic anaemia or a high reticulocyte count.

\section{Results}

The results are presented in Tables 1 and 2 .

Group 1. In the families whose children had cataracts (families 1-12) we did not observe significantly reduced galactokinase or uridyltransferase activities in either the mothers or the offspring. The mean values of these enzymes in the mothers were not significantly different from the control means.

Group 2. In the families with mothers having partial galactokinase deficiency (families 13 and 14) or partial uridyltransferase deficiency (families 15-19) no cataracts were found in the children in the absence of an homozygote defect. In some healthy children enzymatic activities were not assayed.

\section{Discussion}

We have explored two groups of patients.

The first group presented 'inexplicable' and early onset cataracts in children with normal galactokinase and uridyltransferase activities. We did not find any abnormalities of galactose metabolism in their mothers.

The second group had a partial galactose metabolism deficiency in the mother. No children of these women had cataracts (except the galactosaemic homozygotes). All the pregnancies were allowed to proceed without any restriction of the diet. Nothing is known of the actual milk intake of these mothers during their pregnancy.

These results are disappointing compared with previously reported findings, which hypothesised that a partial enzymatic deficiency in the mother might be responsible for the inexplicable cataracts in some children. 56

Harley et al have measured galactokinase and uridyltransferase activities in erythrocytes from children with unexplained cataracts, their parents, and matched controls. ${ }^{5}$ The mean galactokinase activity in the mothers was significantly lower than that of women controls. No such difference could be shown between the children with cataracts or their fathers and the control group. In our experience the mean galactokinase activity in the mothers with children who had cataracts was not significantly different from the control mean.

Winder et al have reported partial maternal deficiency of galactokinase and transferase activities in 10 families with early onset cataracts. ${ }^{6}$ In three families a low lactose diet was prescribed during subsequent pregnancies: two unaffected children were born, but a child with cataracts arose from the third pregnancy. In contrast, our results show that our seven heterozygote mothers had normal children despite the absence of any dietary restriction.

Although plasma lactose concentration (and urinary lactose excretion) increase from the 18th week of pregnancy, ${ }^{11}$ it is doubtful whether an appreciable proportion of the circulating lactose is converted into circulating glucose and galactose. Intravenous administration of lactose has been reported not to raise blood glucose concentrations in humans and rats. ${ }^{12}$ During pregnancy excretion of galactose is not above normal even in women with a reduced galactose metabolism. ${ }^{13}$

The galactokinase activity in the fetal liver is greater than in the adult organ and is reported to be more responsive to plasma galactose concentration. ${ }^{1415}$ This may well offer a measure of protection to the fetal lens.

The development of cataracts in the fetus is likely to be the final common pathway of a variety of biochemical insults. Previous studies in the rat noted histological evidence of damage to the fetal lens when pregnant women ingested a diet unusually rich in galactose $(40 \%){ }^{16}$ In human beings cataract formation in the fetus of an heterozygous mother probably depends on several factors, such as large milk intake, maternal hepatic dysfunction, or mild biochemical 'intolerance'. After an intravenous loading test with $0.35 \mathrm{~g} / \mathrm{kg}$ body weight, the half life of galactose and excretion of galactitol are significantly increased in some individuals heterozygous for galactokinase deficiency. ${ }^{17} 18$

Protective mechanisms, however, seem to exist in the fetus. The history of family 19 argues for a specific fetal protection. An heterozygous woman for uridyltransferase deficiency developed cataract during the third trimester of her first pregnancy, and again during her second pregnancy. The two children born of these two pregnancies had normal lenses, the first one was heterozygous for uridyl- 
transferase activity, the second had normal enzymatic activities. A similar observation has been previously described. ${ }^{19}$

In contrast to other studies, our results do not suggest any direct link between maternal partial galactose disorders and infantile cataracts. More data are needed, however, before previous findings can be ascribed to fortuitous associations.

\section{References}

1 Segal S. Disorders of galactose metabolism. In: Stanbury JB. Wyngaarden JB, Frederickson DS, et al. eds. The metabolic basis of inherited disease. New York: MacGraw Hill, 1983: 167-91.

2 Prchal JT, Conrad ME, Skalka HW. Association of presenile cataracts with heterozygosity for galactosaemic states and with riboflavin deficiency. Lancet 1978;i:12-3.

${ }^{3}$ Montelcone JA, Beutler E, Monteleone PL. Utz OL. Cascy EC. Cataracts, galactosuria and hypergalactosemia due to galactokinase deficiency in a child. Am J Med 1971:50:4(13-7.

${ }^{+}$Beutler E. Matsumoto F. Galactokinase and cataracts. Lancet 1978:i:1161.

${ }^{5}$ Harley JD, Mutton P. Irvine S. Gupta JD. Maternal enzymes of galactose metabolism and the "inexplicable" infantile cataract. Lancet 1974;ii:259-61.

' Winder AF, Claringbold LJ, Jones RB, et al. Partial galactose disorders in families with premature cataracts. Arch Dis Child 1983:58:362-6.

7 Shin-Buchring YS, Osang M, Ziegler R, Schaub J. A simple assay for galactokinase using DEAE cellulose column chromatography. Clin Chim Acta 1977:74:1-5.

${ }^{\rtimes} \mathrm{Ng}$ WG, Bergren WR, Donnell GN. An improved procedure for the assay of hemolysate galactose-1-phosphate uridyltransferase activity by the use of ${ }^{14} \mathrm{C}$-labelled galactose-1-phosphate. Clin Chim Acta 1967:15:489-92.

" Ng WG, Donnell GN, Bergren WR. Galactokinase activity in human erythrocytes of individuals at different ages. $J$ Lab Clin Med 1965;66:115-21.

11" Ibbott FA. Shapcott D. Berry HK. Beutler E. A screening procedure and a specific quantitative method for UDP glucose: $\alpha$-D-galactose-1-phosphate uridylyltransferase (EC 2.7.7.12.). Clin Chem 1977:23:1348-55.

1 Date WJ. The excretion of lactose and some monosaccharides during pregnancy and lactation. Scand J Clin Lab Invest 1964:16:589-96.

12 Weser E, Sleisenger MH. Metabolism of circulating disaccharides in man and the rat. $J$ Clin Invest 1967:46:499-505.

13 Mellman WJ, Rawnsley BE, Nichols CW, et al. Galactose tolerance studies of individuals with reduced galactose pathway activity. Am J Hum Genet 1975;27:748-54.

it Shin-Buehring YS, Beier T, Tan A. Osang M. Schaub J. The activity of galactose-1-phosphate uridyltransferase and galactokinase in human fetal organs. Pediatr Res 1977:11:1003-9.

15 Cuatrecasas P. Segal S. Mammalian galactokinase: developmental and adaptive characteristics in the rat liver. J Biol Chem 1965;240:2382-8.

16 Segal S. Bernstein H. Observations on cataract formation in the newborn offspring of rats fed a high-galactose diet. J Pediatr 1963:62:363-70.

17 Sitzmann FC. Kaloud H. Biokinetics of galactose in the homozygotes and heterozygotes of both forms of galactosemia. Clin Chim Acta 1976:72:343-51.

${ }^{1 x}$ Sitzmann FC, Schmid RD, Kaloud H. Excretion of galactitol in the urines of heterozygotes of both forms of galactosemia. Clin Chim Acta 1977:75:313-9.

19 Avisar RA. Schwartzman S, Levinsky H, et al. A case of cataract formation during the lactating period associated with galactose-1-phosphate uridyltransferase deficiency. Metab Pediatr Syst Ophthalmol 1982:6:45-8.

Correspondence to Dr M Brivet, Laboratoire Central de Biochemie. Pr A Lemonnier, Hôpital Bicêtre, rue de Général Leclerc. 94275 Le Kremlin-Bicêtre, France.

Received 16 January 1986 